\title{
The Effect Of Dimension Companies On The Level Of Debt: A Study Of The Fishing Industry In Spain
}

Lucy Amigo-Dobaño, Universidad de Vigo, Spain $\mathrm{M}^{\mathrm{a}}$ Dolores Garza-Gil, Universidad de Vigo, Spain Manuel Varela-Lafuente, Universidad de Vigo, Spain

\begin{abstract}
The present concern that exists in the economy on account of the high level of debt facing nonfinancial companies in Spain also exists in the fish and seafood processing industry, particularly to the extent that it might affect the fisheries sector as a whole. Given that Spain has generated an important processing sector and has become the main producer of canned fish and seafood in the $E U$, it is undoubtedly a pertinent case of reference to analyse this problem. Along these lines, this study specifically looks at the economic structure and financial viability of the canning industry in Spain's largest area of production (Galicia), analysing the possible interrelationships that may exist between debt levels and the business structure in this sector of the economy. Furthermore, the study is carried out in a scenario of increased demand and of risks associated with international competition, which makes the implementation of competitive strategies to guarantee the future of this activity recommendable. The results obtained show the existence of a close relationship between the size of the companies and the debt level.
\end{abstract}

Keywords: Renewable Resources, Fishery, Canned food Industry

\section{INTRODUCTION}

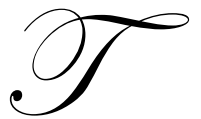

he evolution of the Spanish GDP, and particularly in Galicia, has seen significant rises in recent years. However, at present, certain concern for the high level of debt faced by Spanish non-financial companies exists. With this scenario in mind, our intention is to provide empirical evidence of the state of the business structure in Galicia. From this consideration, our study will analyze empirically the situation of the companies in Galicia and, especially, the canned fish food industry, for the importance that they suppose for the Galician economy.

Data relating to the active non-financial companies in the Autonomous Community of Galicia reveals a business sector made up of a total of 49,901 companies in 2006, which represents approximately $5.37 \%$ of the total number of companies in Spain, the leading places being Madrid and Barcelona, representing around 17\% and 16\%, respectively. With regard to the size of the Galician companies, when analysed, the verified data show no great difference from the national average which, given Spain as a whole, suggests that approximately $64 \%$ of active companies can be considered small, with a staff of less than 20 employees. The fact that small companies in Galicia represent $70 \%$ of the total number of companies considered is a fair reflection of the Galician business structure, in which small-sized companies are predominant.

In Spain, fishing is one of the most important activities within the European Union, and this has given rise to the emergence of an important processing and commercialisation sector located principally in Galicia. The growth in consumption per capita of marine products on a worldwide scale is not only related to an increase in extractive and aquaculture capacity in the marine environment, but also to the capacity to conserve and process the product in order to increase the possibilities of such highly perishable goods being consumed, as well as adapting to the tastes and needs of consumers. 
On the other hand, although the processing sector can be catalogued, in general, within traditional manufactured goods, it is presently undergoing technological changes, as well as changes in the degree of product standardisation. Therefore, the analysis of its economic and financial viability can indicate its potential for development in the immediate future.

In order to progress in this direction, we have chosen the case of Spain whose fisheries sector is of significant importance, both with regard to the extractive aspect as well as to the processing industry. In particular, the study refers to Galicia, the most important region in Spain insofar as production and employment in the sector is concerned (59.7\% of the total value produced in Spain and 38,300 jobs, of which 10,800 correspond to the processing sector), focusing on the canned fish sub-sector, the most significant in Spain's case.

In fact, according to data from the FAO, $12 \%$ of the world's fish consumption takes place in the canned form, this figure reaching $25.6 \%$ in developed countries (FAO, 2007). Furthermore, approximately 50\% of the world's canned fish and seafood production is focussed in five countries (FAO, 2004). Heading this list is Thailand with $23 \%$ of production, followed by Spain with $10 \%$ of the world's production. On a European level, at the top of the list is Spain, where approximately 50\% of EU production was concentrated in 2005.

On the other hand, the volume of production of Spanish canning companies has increased by around $42 \%$, reaching a figure of 325,000 tonnes in 2006. Within Spain as a whole, the canning industry in Galicia, mainly characterised by family businesses, produces approximately 260,000 tonnes, which represents $80 \%$ of the national total. In Galicia, at present there are 64 canning companies - 147 operational on a national level, which employ 6,912 workers $-15,500$ workers on a national level ${ }^{1}$.

From this perspective, the aim of this study is to analyse the economic and financial structure of the companies in Galicia and particularly of the sector chosen, with the end aim of detecting possible situations of weakness which might generate processes of economic unsustainability or production delocalisation, such as those that have occurred in recent years in Europe, as Catarci (2004), Ruesga and Da Siva (2004) and Schmidt (2004) point out $^{2}$. In particular, we aimed to obtain parameters that make it possible to value the present economic and financial structure of the canning industry in Galicia in terms of its business size and, in this way, to illustrate the strategic possibilities of the sector in the future.

In this context, most literature focuses on analysing the fisheries sector on a worldwide level from different perspectives, starting from the present scenario dominated by an increase in fish catches due to the growing demand for food for human consumption (Josupeit and Catarci, 2004). However, few studies have focused on analysing the canning sector in particular, as Núnez (2006) shows for the case of Spain. Considering the interrelationships between the financial structure and business size, the studies by Harris and Raviv (1991), Booth and others (2001), Fama and French (2002), and Griannetti (2003), among others, stand out. Within the Spanish framework, the empirical studies carried out have not been homogenous insofar as the results achieved are concerned. We would underline the studies by Ocaña, Salas and Vallés (1994), Fariñas and Suárez (1999) and Acedo, Ayala and Rodríguez (2005), which do not verify a relationship between the level of debt and the business size, and the studies by Mato (1990), Fariñas et al. (1992), Menéndez Requejo (2001), Segura and Toledo (2003) and Jiménez and Palacín (2007), who do find evidence of an interrelationship between these variables, verifying through their studies different types of relationships.

Bearing in mind these coordinates and references, our study will be structured as follows: in the second section, we present the economic structure of the Spanish, Galician companies, especially Galician canning companies. In section three, we will analyse the financial equilibrium using the analysis of variance (ANOVA) method, and in section 4, we will set out the main conclusions.

\section{THE DATA: ECONOMIC STRUCTURE OF THE COMPANIES}

The database used in the study is made up of the Spanish companies and the Galician fish and seafood canning sector. Specifically, we have obtained the economic and financial data series for this segment of the fisheries sector from Informa D\&B, S.A and SABI. The analysis of the characterisation of Spain's and Galicia's 
business sectors, insofar as the size of the company is concerned, shows a similar trend. The verified data for the Galician economy do not differ much from the data relating to the national average. The data for Spain, as a whole, suggest that approximately $64 \%$ of active companies can be considered small, as they have less than 20 employees. The fact that small businesses in Galicia represent $70 \%$ of the total number of companies considered is a fair reflection of the Galician business structure, in which small-sized companies are predominant.

With the aim of reflecting the financial situation of companies in Galicia and, in particular, disaggregating the analysis at the level of the four Galician provinces, the variables used to express the relationship that exists between the debt capital and the total resources of companies as an indicator of the debt level are set out in Table 1. These results show that Galicia has a high level of business debt, as it can be verified that approximately $20.23 \%$ of the companies have a debt level of between $50 \%$ and $75 \%$; in $37.37 \%$ of the companies, the level of external financing stands between $75 \%$ and $100 \%$; and $18.76 \%$ of the companies even have a debt level higher than $100 \%$. For their part, only $23.64 \%$ of Galician companies have a debt level lower than $50 \%$. The national average is also high, although slightly lower. In any case, these are the first generic results which could be developed further, bearing in mind relevant determining factors in the debt level, such as the sector and business size. The study's next step will be to analyse the debt level for the canned fish sector in Galicia and to verify if this debt level bears any relationship to the size of the company.

Table 1: Levels of Debt of the Companies in Spain (2006)

\begin{tabular}{|c|c|c|c|c|c|}
\hline & $\begin{array}{c}\text { Debt Level } \\
\leq \mathbf{2 5 \%} \\
\text { (\%companies) }\end{array}$ & $\begin{array}{c}\text { Debt Level 25\%- } \\
50 \% \\
\text { (\% companies) }\end{array}$ & $\begin{array}{c}\text { Debt Level 50\%- } \\
75 \% \\
\text { (\% companies) }\end{array}$ & $\begin{array}{c}\text { Debt Level } 75 \% \text { - } \\
100 \% \\
\text { (\% companies) }\end{array}$ & $\begin{array}{c}\text { Debt Level } \\
\geq 100 \% \\
\text { (\% companies) }\end{array}$ \\
\hline La Coruña & 11,78 & 13,39 & 20,20 & 36,04 & 18,59 \\
\hline Lugo & 12,03 & 13,37 & 22,50 & 37,42 & 14,68 \\
\hline Orense & 11,02 & 13,12 & 21,62 & 37,50 & 16,75 \\
\hline Pontevedra & 10,18 & 11,29 & 19,22 & 38,65 & 20,67 \\
\hline Galicia & 11,10 & 12,54 & 20,23 & 37,37 & 18,76 \\
\hline Spain & 12,90 & 12,51 & 19,42 & 35,57 & 19,59 \\
\hline
\end{tabular}

Source: Own compilation from SABI.

The 64 companies that make up the Galician fish and seafood canning sector can be divided into eight different areas which employed a total of 6,912 personas en 2005: 1) Vigo area (20.84\% of the total turnover for that year), 2) Morrazo area (4.31\%), 3) O Salnés area (6.90\%), 4) Pontevedra area (3.08\%), 5) the Barbanza peninsula $(48.68 \%), 6)$ Costa da Morte area $(3.76 \%), 7)$ North Coruña area (12.28\%), and 8) Lugo (0.12\%).

In general terms, the Galician canning sector is highly concentrated in the Barbanza peninsula, followed by two important areas which are Vigo and the North Coruña areas, with a total turnover for the Barbanza area of approximately 600 million euros in 2005, which represents almost $50 \%$ of the total turnover generated by the entire autonomous community of Galicia.

Table 2: Canning Company Percentage per Tranche of Turnover (2005)

\begin{tabular}{|l|l|l|l|l|l|l|l|}
\hline \multicolumn{1}{|c|}{$\begin{array}{c}\text { Turnover level } \\
\text { (in euros) }\end{array}$} & Companies $(\boldsymbol{\%})$ & $\begin{array}{c}\text { Concentration } \\
\text { employment }\end{array}$ & $\begin{array}{c}\text { Participation } \\
\text { Turnover } \\
(\%)\end{array}$ & $\begin{array}{c}\text { Participation } \\
\text { Profit } \\
(\%)\end{array}$ & $\begin{array}{c}\text { ROI } \\
\text { Average } \\
(\%)\end{array}$ & $\begin{array}{c}\text { ROI } \\
\text { Typical } \\
\text { deviation }\end{array}$ & $\begin{array}{c}\text { Debt } \\
\text { level } \\
(\%)\end{array}$ \\
\hline$\leq 600,000$ & 10.94 & 1.21 & 0.14 & 0.26 & 3.47 & 4.52 & 99,14 \\
\hline $600,000-2,000,000$ & 15,63 & 3.56 & 0.77 & 2.49 & 5.11 & 4.10 & 51.40 \\
\hline $2,000,000-3,000,000$ & 18,75 & 5.96 & 2.16 & 2.93 & -5.13 & 11.88 & 69.31 \\
\hline $3,000,000-6,000,000$ & 17,19 & 7.17 & 3.40 & 12.46 & -1.93 & 21.80 & 61.56 \\
\hline $6,000,000-30,000,000$ & 18,75 & 20.04 & 12.98 & 11.47 & 2.21 & 2.80 & 57.79 \\
\hline $30,000,000-196,298,252$ & 18,75 & 62.06 & 80.56 & 71.00 & 1.83 & 4.46 & 56.71 \\
\hline TOTAL & 100,00 & 100.00 & 100.00 & 100.00 & & & \\
\hline
\end{tabular}

Source: Own compilation from D\&P. 
In order to analyse the solvency of the Galician canning companies in 2005, we will structure the study in terms of their turnover rate. In Table 2 we present the participation percentage for each turnover and total profit tranche and their level of debt.

As we can see, and having applied outlier treatment, the sector is highly concentrated, as approximately $18.75 \%$ of Galician companies (those which had an annual turnover of more than 30,000,000 euros) generated $80.56 \%$ of the total turnover in 2005 and $71 \%$ of their profits for that year. For their part, the smaller companies (those which had an annual turnover of less than 2,000,000 euros) represent only a small percentage in the generation of value (around $0.91 \%$ ) and generate $2.75 \%$ of profits. Among these two groups, we were able to differentiate between an important volume of companies which could be classified as small (those which turned over between 2,000,000 and 30,000,000 euros per year), representing approximately 50\% of companies and generating $18.54 \%$ of the total turnover and $24.86 \%$ of total profits.

In Table 2, information is also given on the annual economic profitability of each of the companies considered as this is an ideal indicator of companies' returns on investment (ROI) ${ }^{3}$. The results obtained ratify, as was foreseeable, what has been stated so far.

\section{EMPIRICAL ANALYSIS}

We could identify the financial soundness of companies with the guarantee that they offer their creditors to pay off their debts and, in this sense, it is provided by a direct relationship between the company's real assets and its total debt. The debt ratio (see Table 2) shows that an important variability in financial soundness exists between the different canning companies in accordance with their turnover levels. Specifically, the percentage of assets financed by debt capital is extremely high for the small-sized companies, with figures that even reach levels of 90 percent for companies with annual turnovers of less than 600 thousand euros. The level of debt capital could be established at around $65 \%$, which therefore is situated at bearable, if high, levels. Finally, the large companies reflect a healthier financial situation, with debt levels of around $54 \%$, which therefore is at a safer distance from the maximum threshold of bearable debt.

In this sense, the values reached to describe the financial situation of the Galician canning companies mark a pattern of behaviour that supports the idea widely held within the business sector in Spain, as a whole, that their degree of financial healthiness matches their size, measured by their turnover levels. In particular, in our sample it is significant to point out that the most critical levels, insofar as financial healthiness is concerned, are to be found in the smaller-sized companies being high, but bearable, for the medium-sized companies. For their part, the large companies are the ones in a situation where most of their assets are covered by equity and, therefore are in a better situation of financial equilibrium. The critical situation of the small and medium-sized companies may be linked to a large extent to the difficulties they find in accessing the financial markets directly and their dependence on shortterm financing, which increases the cost of financing and hinders it with respect to the larger companies. At the same time, the financing of the small-sized companies brings with it on numerous occasions not only the guarantee of a return on the investment, but also the added guarantees that are usually contingent with equity.

The analysis of the data provided enables us to gauge the importance of the size of the company and the economic and financial results of the canning industry. With the aim of verifying if, on average, the behaviour of the debt level and the average annual economic results obtained are identical regardless of the business size of the industry, we will follow the analysis of variance (ANOVA) methodology ${ }^{4}$. The aim will be to test whether the categorical variable, which defines the different groups of business size, differs in the debt variable and the sector's financial results. With the aim of making the estimations more robust, Tables 3 and 4 show the results for the period 2003-05. 
Table 3: Analysis of Variance for the Business Size Factor (2003-2005)

\begin{tabular}{|c|c|c|c|c|c|c|}
\hline & \multicolumn{6}{|c|}{ Quantitative variable : Debt level } \\
\hline & & $\begin{array}{l}\text { Sum of } \\
\text { squares }\end{array}$ & df & $\begin{array}{c}\text { Quadratic } \\
\text { average }\end{array}$ & $\mathbf{F}$ & Sig. \\
\hline \multirow{3}{*}{2003} & Inter-groups & $5.37 .10^{15}$ & 5 & $1.08 .10^{15}$ & 7.042 & 0.000 \\
\hline & Within-groups & $7.23 .10^{15}$ & 48 & $51.53 .10^{15}$ & & \\
\hline & Total & $1.27 .10^{16}$ & 53 & & & \\
\hline \multirow{3}{*}{2004} & Inter-groups & $8.32 .10^{15}$ & 5 & $1.66 .10^{15}$ & 6.045 & 0.000 \\
\hline & Within-groups & $1.40 .10^{16}$ & 51 & $2.75 .10^{14}$ & & \\
\hline & Total & $2.23 .10^{16}$ & 56 & & & \\
\hline \multirow{3}{*}{2005} & Inter-groups & $8.31 .10^{15}$ & 5 & $1.66 .10^{15}$ & 4.126 & 0.003 \\
\hline & Within-groups & $1.93 .10^{16}$ & 48 & $54.03 .10^{14}$ & & \\
\hline & Total & $2.76 .10^{16}$ & 53 & & & \\
\hline
\end{tabular}

*df: degrees of freedom associated with each sum of squares.

*Fisher-Snedecor F statistic: the quotient between two estimators of population variance: estimator obtained from the variation that exists between the group averages (Inter-group variation) and estimator obtained from the variation that exists between the punctuations within each group (Intra-group variation).

*Sig: critical level of level of signification of the F statistic.

Source: Own compilation.

Table 4: Analysis of Variance of the Business Size Factor (2003-2005)

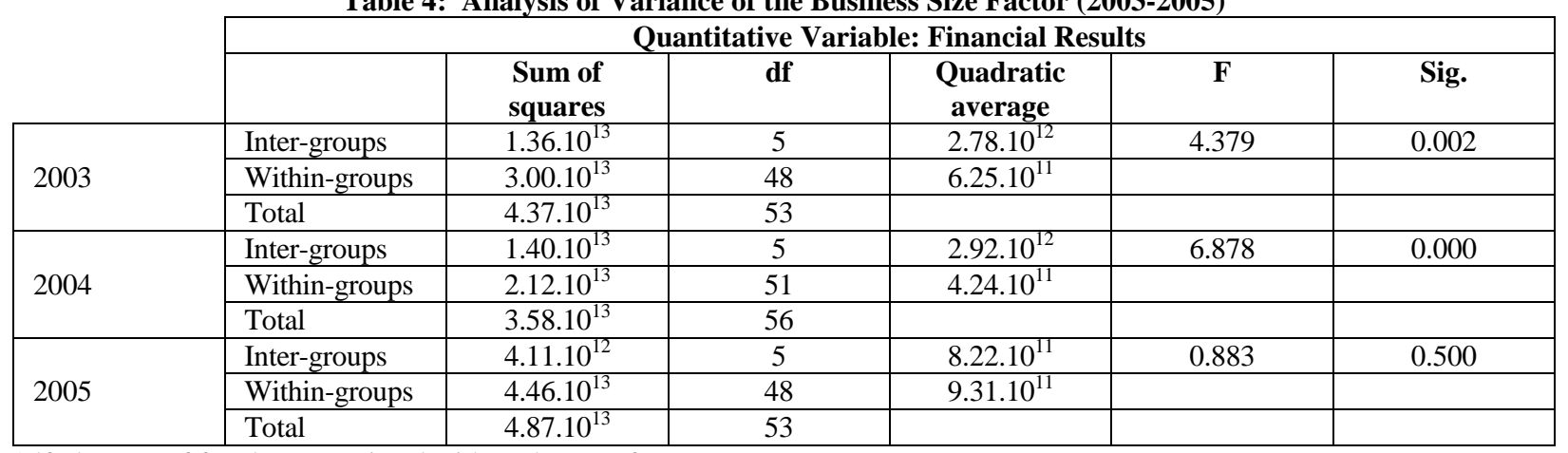

*df: degrees of freedom associated with each sum of squares.

*Fisher-Snedecor F statistic: the quotient between two estimators of population variance: estimator obtained from the variation that exists between the group averages (Inter-group variation) and estimator obtained from the variation that exists between the punctuations within each group (Intra-group variation).

*Sig: critical level of level of signification of the F statistic

Source: Own compilation.

The results of the ANOVA test carried out for the size factor leads us to reject the null hypothesis when the variable indicating the level of debt is the quotient of debt capital among total resources. This allows us to affirm that for 2005 and also for the preceding years, the business size factor significantly influences the definition of the companies' financial structures statistically.

Next, and once it has been verified that the companies' financial structure differs according to their size, we will complete the study by identifying which one is the different group and with respect to which of the remaining groups significant differences exist. The carrying-out of multiple comparison tests allows us to affirm that the larger companies act in a different way statistically to the small and medium-sized ones, verifying that the latter are the least in debt. With respect to the variable that indicates the annual financial results, the variance analysis leads us to affirm that for 2003 and 2004, the business size factor significantly influences the structure of the business results, although in 2005 , the results indicate that this factor is not relevant and, therefore, the results achieved can be linked more to business management than its size. 
In short, the existence of a close link between debt levels and business size can be corroborated, the companies which have greater turnover levels reflecting lower debt levels, while the small and medium-sized companies show average debt levels. From the analysis carried out, a favourable situation of equilibrium can be deduced for the large companies, while for the small and medium-sized companies, this situation can be described as weak.

\section{CONCLUSIONS}

Companies, in general, canning companies too, are presently facing the challenge of assimilating significant and continuous changes, not only environmental, but also social, technological, regulatory and legislative, among others. This makes it necessary to speed up the decision-making process within businesses and institutions in order to adapt to this changing and complex world. This process requires developing all of a company's potential; therefore, it is necessary to know, in detail, what their economic structure is in order to ensure not only that optimum levels of profitability are reached, but also from a perspective of sustainable medium and long-term economic growth.

The financial results of the fish and seafood canning industry in Galicia indicate a situation in which, in general terms, companies fall within a profit zone. It is worth underlining that greater expectations for the future can be perceived for the more financially healthy companies - the larger ones - as their ratios indicate that by taking on a minimum risk, they will be able to increase their structural burdens. This will allow companies to significantly increase their productive capacity, enabling them to increase their capacity to obtain profits. For their part, with regard to the medium-sized and, in particular, the small-sized companies, it is worth considering the need to implement measures that make it possible to improve their financial situation in search of achieving basic financial equilibrium principles, with the aim of making them economically viable in the medium and long terms.

In short, the empirical analysis shows the need for a plan to economically boost the medium-sized and, especially, the small-sized companies. Parallel to these measures, and given the process of internationalisation in which it is immersed, the canning sector will have to focus its attention basically on searching for added value. An increase in the quality of the products, the search for possible future market niches, increases in investment in $\mathrm{R}+\mathrm{D}+\mathrm{i}$, innovating marketing proposals and improvement in logistic efficiency or the possibility of establishing strategic alliances, among others, is fundamental. All of these contributions can be of special interest on account of the importance of the participation of the canning industry in the economic and social development of Spain and, in particular, for Galicia as a strategic economic activity composite and to the social and economic development of the areas that depend on the sea and its resources.

\section{AUTHOR INFORMATION}

Lucy Amigo Dobaño was born in Caracas (Venezuela) in 1968 and received her BA degree from University of Vigo in 1991. She is PhD in Economics since 2001 and Associate Professor in Department of Applied Economics in University of Vigo since 2002. She is an expert in financial markets and in fisheries economics focusing on econometric modelling, economic analysis fisheries management and regulation. She has participated in several international projects and her research has been published in different national and international journals: among others, Journal of Applied Business Research, International Business \& Economics Research Journal, Review of Financial Markets, Revista Española de Financiación y Contabilidad and Marine Policy.

$\mathbf{M}^{\text {a }}$ Dolores Garza-Gil was born in Vigo (Spain) in 1966 and received her BA degree from University of Santiago de Compostela in 1990. She is PhD in Economics since 1995 and Associate Professor in Department of Applied Economics in University of Vigo since 1998. She is an expert in fisheries economics focusing on bioeconomics modelling, economic evaluation and fisheries management and regulation. She has participated in several international projects and her research has been published in different journals: among others, Marine Policy, Ecological Economics, Environmental and Resources Economics, Disasters, American Journal of Agricultural Economics, Ocean and Coastal Management. 
Manuel Varela-Lafuente is Ph.D in Economics since 1982 and Professor in Department of Applied Economics in University of Vigo, Spain, since 1992. He is an expert in natural resource economics, especially in fisheries economics focusing on economic evaluation and fisheries management and regulation. He has participated in several international projects and his research has been published in different journals: among others, Marine Policy, Fisheries Research, The Journal of Disasters Studies, Policy and Management, American Journal of Agricultural Economics, Ocean and Coastal Management.

\section{REFERENCES}

1. Acedo, M.; Ayala, J; Rodríguez, J. (2005): "Rentabilidades, endeudamiento y coste de la deuda de las pymes. Análisis empírico de las empresas por tamaños", Revista Europea de Dirección y Economía de la Empresa, núm. 14,4, pp. 185-200.

2. ANFACO (1996): Aplicación del sistema de análisis de riesgos y control de puntos críticos en conservas de productos de la pesca. Vigo: Anfaco.

3. ANFACO (2000): Estudio de la demanda tecnológica y de investigación en la industria de transformación de productos del mar. Vigo: Oficina de Transferencia de Resultados de Investigación/Anfaco/Cecopesca.

4. Booth, L; Aivazian, V.; Demirguc-Kunt, A.; Makisimovic, V. (2001): "Capital Structure in Developing Countries", Journal of Finance, no. 56, pp. 87-130.

5. Catarci, C. (2004): "The World Tuna Industry. An Analysis of Imports and Prices, and of Their Combined Impact on Catches and Tuna Fishing Capacity". Roma: FAO, Fisheries Department.

6. Espinosa, E. (2006): "O libro Blanco de la Pesca: un instrumento para a competitividade”, Revista Galega de Economía, ISSN 1132-2799, Vol. 15, núm. 1, pp. 267-271.

7. Fama, E.; French, K. (2002): “Testing Trade-Off and Peeking Order Predictions about Dividends and Debt", The Review of Financial Studies, no. 15, 1, pp.1-33.

8. FAO (2004): Cites Issues with respect to the International Fish Trade. Bremen.

9. $\quad$ FAO (2007): The State of World Fisheries and Aquaculture 2006. Rome.

10. Fariñas García, J.C.; Suárez Galvéz, C. (1999): “Financiación”, en J.C. Fariñas García y J. Jaumandreu Bala (coord.): La empresa industrial e la década de los noventa, pp. 143-163, Madrid, Fundación Argentaria.

11. Fariñas, J.C. ; Calvo, J.L.; Jaumandreu, J.; Lorenzo, M.J.; Iglesia, C. de la (1992): "La Pyme industrial en España. Madrid, Civitas.

12. Griannetti, M. (2003): "Do Better Institutions Mitigate Agency Problems? Evidence from Corporate Finance Choices", Journal of Finance and Quantitative Analysis, no. 38, 1,pp. 185-211.

13. Harris, M; Raviv, A.(1991): "The Theory of Capital Structure”, Journal of Finance, no. 46, 1, pp. 297-355.

14. Jiménez; Palací, M.J. (2007): "Determinantes de la estructura financiera de la empresa", Revista Europea de Dirección y Economía de la Empresa 16(4), 9-23.

15. Josupeit, H.; Catarci, C. (2004): "The World Tuna Industry-an Analysis of Imports, Prices, and of Their Combined Impact on Tuna Catches and Fishing Capacity", FAO.

16. Mato, G. (1990): "Estructura financiera y actividad real de las empresas industriales", Economía Industrial, núm. 272, pp. 107-114.

17. Menéndez Requejo, S. (2001): "Endeudamiento de pymes vs grandes empresas: determinantes y relaciones estructurales", IX Foro de Finanzas, Navarra.

18. Núñez, R. (2006): “Las empresas conserveras y el mercado mundial del atún”, Revista Galega de Economía, ISSN 1132-2799, Vol. 15, núm. 1, pp. 1-20.

19. Ocaña, C.; Salas,V.; Vallés, J. (1994): "Un análisis empírico de la financiación de la pyme manufacturera española", Moneda y Crédito, núm. 199, pp.57-96.

20. Ruesga, S.M.; Da Siva, J. (2004): "Direct Spanish Foreign Investment in Latin America: Determinants and Company Strategy", Canadian Journal of Development Studies, vol. XXV, no. 2, pp. 321-335.

21. Schmidt, C. (2004): Globalisation, Industry Structure, Market Power and Impact on the Fish Trade Opportunities and Challenges for Development (OECD) Countries. París: OECD.

22. Segura, J.; Toledo, L. (2003): "Tamaño, estructura y costes de financiación de las empresas manufactureras españolas”, Investigaciones Económicas, vol. 27, pp. 39-69. 


\section{FOOTNOTES}

\footnotetext{
${ }^{1}$ Among all of the canned products the sector produces, tuna is the most important, followed by sardines and mackerel, whose volume of production has also increased, whereas the production of others, such as octopus, squid, cockles, razor clams and clams, has decreased. National Association of Fish and Seafood Canners. See Anfaco (1996, 2000) and Espinosa (2006).

${ }^{2}$ The process involving the delocalisation of the European canning industry was caused to a large extent by growing investment made by European countries in Central and South American countries, stimulating increases in production in those countries.

3"Return on investment" is one of the most-used organisational performance measurements in literature. Equity is the difference that exists between contingent assets and liabilities.

${ }^{4}$ The ANOVA analysis is a type of linear model in which the explanatory variable is categorical. This allows us to compare the group averages bearing in mind the variability of the observations within each group. The application of the ANOVA statistical technique required that the fulfilment of homocedastitcity conditions was verified previously with the application of the Levene statistic and normality of the dependent variables through the Kolmogorov-Smirnov test.
} 